\title{
An Inquiry into Chinese Initial Public Offerings from a Corporate Governance Perspective
}

\author{
Guclu Atinc \\ Drake University • Des Moines, IA \\ Yan Liu \\ United States University • San Diego, CA \\ Mark Kroll \\ University of Texas at Brownsville • Brownsville, TX \\ Bruce A. Walters \\ Louisiana Tech University • Ruston, LA
}

\begin{abstract}
Using longitudinal data, this study investigates the impact of managerial ownership, director ownership, state ownership, firm size, and blockholders on initial public offerings (IPOs) of Chinese listed companies from 1991 to 2007. Underpricing of IPOs is examined at three specifically identified time periods which we call the primitive stage, the development stage, and the maturity stage. Our results indicate that those corporate governance factors we examined in this study exhibit different characteristics at different stages for Chinese publicly listed companies which signify a need to assess the impact of governance mechanisms on IPO processes of emerging economies from a different perspective.
\end{abstract}

\section{Introduction}

This study examines the initial public offerings of Chinese publicly traded companies and illuminates some of the unknowns of this dynamic economy. The process of China's market economy reform has been experimental and gradual. Since the reform started in 1978, there has been remarkable growth in the Chinese economy. Since the two Chinese stock markets were formed in the early 1990s, hundreds of companies have been privatized and have gone public (Sun, Li, \& Zou, 2005). Although the idea was to create a free market economy in which business practices reflect those of western counterparts, scholars call for more in-depth studies about the uniqueness of the Chinese quasi-free-market structure (Firth, Fung, \& Rui, 2006; 2007).

Popular research areas such as corporate governance of listed firms (Chen, 2001) and State-Owned-Enterprises (Hua, Miesing, \& Li, 2006) have been investigated, while initial public offerings (IPOs) and related issues have only recently received attention (Deng \& Dorfleitner, 2008; Kao, Wu, \& Yang, 2009). Sanders 
and Boivie (2004) proposed that in emerging industries, there are qualitative factors rather than objective factors that serve as signals for the valuation of firms. The authors argue that "in highly uncertain environments investors attempt to reduce their uncertainty through screening firms and sorting their valuations based on new firms' use of observable agency control mechanisms" (Sanders \& Boivie, 2004: 170). Going beyond that, this study considers some of these observable mechanisms and makes a connection between them and IPO firm performance in China. There is evidence characterizing the Chinese IPO market as one in which there is a prevalence of uncertainty and information asymmetry (Ma, 2007). As China is considered a rising star in the 21 st century, assessing the progress of the IPO process in China is important. Particularly, this study assumes that different governance mechanisms may have different impacts on firm valuation at different points in time in the evolution of the Chinese new issue market.

Although the study is retrospective, the results may provide insights into the future of the Chinese IPO market and IPO markets in other emerging economies. This study examines the impact of managerial ownership (Kroll, Walters, \& Le, 2007), director ownership (Kroll, Walters, \& Wright, 2008), firm size (Dalton, Daily, Johnson, \& Ellstrand, 1999), state ownership (Sun et al., 2005), and blockholders (Daily, Dalton, \& Rajagopalan, 2003) on IPO underpricing (Arthurs, Hoskisson, Busenitz, \& Johnson, 2008) at three specific points in time. A review of the literatural indicates that an explanation of the temporal changes in the relationships between firm governance and IPO performance has not been done. This study provides a road map for academicians in analyzing the impact of governance issues on IPOs in emerging economies and provide fresh insights into the impacts of various corporate governance devices in emerging economies that are likely to differ from earlier findings related to mature western markets.

\section{Conceptual Development}

Classical agency theory proposes that executives act as agents of the shareholders or principals (Jensen \& Meckling, 1976). The theory suggests that more vigilance by the board should result in better monitoring of the agents and ultimately better performance (Kroll, Wright, \& Elenkov, 2002). However, some scholars consider the presence of executives on the board to be positively related to IPO performance for younger entrepreneurial firms (Kroll et al., 2007). The contention of this study is that there are other exceptions to the general prescriptions of agency theory involving transition economies. 
We divide the development process of the Chinese primary market into three different eras. The first era starts with the formation of Shanghai and Shenzhen stock markets from the end of 1990 through 1995. The second era begins in early 1996 and goes through the end of 2000. Finally, the third era starts in 2001 and ends in 2007. Note that in all three stages, companies were operating in a stable environment initially; then enter a period of rapid change, and then return to stable environments as proposed by the punctuated equilibrium theory, (Gersick, 1991) although our intention is not solely to rely on this theory to explain the differences between the three stages. The companies going public in the first stage experienced the dynamism of the move to a free market economy, while in the second stage, companies experienced the Asian currency crisis. The companies going public in the third stage also experienced an economic downturn following the turn in the millennium.

Further support for this distinction is also documented in the literature. First, Ibbotson, Sindelar, and Ritter (1988) reported that market cycles can be identified by taking the relationship between IPO activity and initial returns (underpricing) into consideration. Furthermore, popular IPO studies make use of at least five-year data to account for macroeconomic conditions (e.g. Jain \& Kini, 1994). Zhou and Zhou (2011) reported the differences in the number of IPOs between the first fiveyear period and the remaining time frames of the Chinese stock markets. In another study, the same authors documented the sudden changes in IPO markets after 2001 due to relaxation of the use of foreign currency in stock price determinations (Zhou \& Zhou, 2010). China's entry into the World Trade Organization in December 2001 also sets this year as a milestone. Finally, the Chinese Securities and Exchange Commission restricted the IPO activities from the second half of 2005 to the first half of 2006. Hence, considering the 2001-2007 period as a whole is not only useful from a theoretical perspective but also makes practical sense by accounting for the sudden cessation of IPO activities as well. In summary, we propose that in the Chinese market, market players, such as the investors, the underwriters and the executers of corporate governance, were initially inexperienced and started to learn about market mechanisms during the first era. As those market players gained practical knowledge and enhanced their level of experience, they were able to make more intelligent decisions. By the time the last era arrived, market players became well aware of the market mechanisms just like their western counterparts, indicating that the Chinese market had reached a level of maturity, and henceforth, participants are likely to behave more like their western counterparts. Le, Kroll, and Walters (2010) developed a framework for assessing the applicability of various corporate governance mechanisms across three stages that transition economies experience. In an article, the 
authors adopted an institutional theory perspective to demonstrate the effectives of different corporate governance mechanisms in three different stages of transitional economies. Building on their work, we adopt primarily a signaling theory perspective to demonstrate how the behavior of market players differ in each of the three stages and then provide a road map for academicians and practitioners to assess the transition process in emerging economies in terms of corporate governance mechanisms and IPO performance.

During the first stage, we speculate that companies going public suffer from the "liability of newness" (Stinchcombe, 1965) as managers of those companies are inexperienced about being publicly traded and have to cope with the legal requirements of the governing bodies which are also inexperienced with regard to regulating market transactions. In this case, one can speculate that classical contentions of agency theory about the board of directors are less likely to apply (Kroll, et al., 2007). In the Chinese context, at least initially, the board characteristics that western scholars assume to be important, such as meeting the board vigilance requirements of agency theory (Kroll et al., 2008), may not be fulfilled. For example, in the first era there were not enough experienced outsiders to adequately staff the boards of directors of all the firms going public. Therefore we anticipate Chinese firms, on average, started with a relatively greater number of executives on their boards.

As market participants such as executives, board members, regulatory bodies, outsiders, and other shareholders learned through interaction with their Western counterparts and more executives gained oversight experience, the popularity of outside board members increased. In fact, as with the Sarbanes-Oxley Act of 2002 in the United States, the Chinese Securities Regulatory Commission (CSRC) now recommends that at least two independent outsiders be present on corporate boards. In summary, Chinese companies likely started with more executives (insiders) on their boards and moved towards board independence along the way. This probably happened naturally as the Chinese companies mimicked their western counterparts due to institutional isomorphism (DiMaggio \& Powell, 1983). In parallel to this, companies should also have started with little or no executive ownership but moved toward more executive ownership, which is gathered through more performance based compensation schemes (Wright \& Kroll, 2002). Western scholars recommend some amount of executive ownership to mitigate conflicts of interest between the executives and shareholders (Buchko, 1992).

Wang (2005) investigated whether different types of owners have different impacts on Chinese firms' performance. He reports that, as a socialist country, 
most Chinese publicly traded companies were originally state owned enterprises (SOEs) and their ownership structure is deeply affected by that fact. In China, companies sell some of their shares to employees, some to legal entities (i.e., other privatized firms and Chinese investment funds), and, public investors. However, it is a well-known fact that the state is still the primary shareholder in a majority of the publicly traded companies (Liu, Atinc, \& Kroll, 2011). In other words, especially in the initial years, the state did not transfer blockholder ownership (over $5 \%$ ) to any of the former SOE executives. In effect, during the primitive stage the executives of the IPO firms were more like government agents, rather than professional executives like their western counterparts. Market players, including the state, learned about different compensation schemes of the west, such as stock options as time passed executives were awarded with more shares in the company as they became more professional. Consistent with the underlying theme of this study, the governance practices have become more westernized as the market matured.

To summarize, although the percentage of executives on the board should have declined as the market moved away from the primitive stage, the percentage of the shares owned by executives should have increased. These changes in the top management team (TMT) structure are considered to be unique for transitional economies and indicate the important connection between the financial improvements at the country level and the corporate governance changes at the organizational level. This study assumes that this connection should be investigated further. The following two hypotheses are based on this discussion:

Hypothesis 1: The percentage of executives on the boards of Chinese listed companies declined as the market moved from one era to the next.

Hypothesis 2: The percentage of shares owned by executives has increased as the market has moved from one era to the other.

IPO underpricing is one of the most popular topics studied concerning. Underpricing refers to the difference between the IPO offer price set by the underwriters and the first day closing price (Arthurs, et al., 2008). When an IPO is first announced, an underwriter acts as the assessor of the value of the firm. Following that, the underwriter sets the offer price and investors are allocated shares by the offering syndicate before the company starts trading. At the end of the first day, what is widely thought to be the true perceived value of the company by the market emerges. If the IPO price is less than its first day closing price, the company's shares were 
underpriced bu the underwriters in the IPO (Heeley, Matusik, \& Jain, 2007). Ritter (1991) referred to this situation as "management leaving money on the table."

In the primitive stage, we assert that underpricing is more likely to happen. In the first years of the Chinese Stock Markets, the IPO mechanisms were not clear and both the underwriters and the investors had little confidence in those mechanisms. On one hand, there was a tremendous amount of information asymmetry between companies and investors so investors had little faith in the price set by underwriters (Fischer \& Pollock, 2004) On the other, underwriters had little confidence that there were sufficient investors who were willing to put their money into early stock offerings. Furthermore, the western-oriented underwriters acted more like agents for investors, rather than investment experts shepherding the focal companies through their IPOs (Arthurs, et al., 2008). For these reasons, underpricing was probably much greater in the primitive stages versus the late 1990s to early 2000 s.

The effect of information asymmetry between issuing firms and investors on underpricing is tremendous (Rock,1986). In the primitive years, China's socialist system was opening stock markets and companies were going public for the first time. There were great information asymmetries concerning the values of these firms. In such a context, firms were likely-to be perceived as being worth much less than they might have actually been worth. However, this situation should have gotten better as time passed and as investors in China better understood the process while gaining more experience with market mechanisms.

Based on the above discussion, we speculate that in emerging economies underpricing is much higher in the initial stages but declines as the market matures. The following hypothesis summarizes this proposal:

Hypothesis 3: Underpricing of IPOs in Chinese markets declined as the market matured through the three stages of development.

Firm demographic characteristics have been investigated by various scholars over the years. For instance, in a western setting, Ibbotson, Sindelar, and Ritter (1988) observed firm size (measured by total revenue) to have a significant influence on the success of the IPO process. Gu (2003) reported firm size (measured by total sales of the issue year) to be positively related to the IPO performance of Chinese companies, contrary to the case in western companies. We extend his finding by considering three different stages of development in the Chinese economy. Specifically, this study proposes that firm size matters more as the market matures. Our choice of firm size as a determinant variable may be questioned. There are other variables (e.g., beta for risk assessment) that can be used as determinant variables 
in IPO-related studies. A review of the literature, though, show firm size to be one of the most widely used and accepted variables in corporate governance-related IPO studies over the years (Gu, 2003; Hand, 2007; Ibbotson, et al., 1988).

In emerging economies, especially in the initial years, people have few investment options. In fact, empirical evidence reflect that in the initial years of the stock market's development in China, investors did not have many firms in which they could invest (Chau, Ciccotello, \& Grant, 1999). Until 1993, there was no formal regulation by the governing bodies regarding information disclosure. For instance, prospectus statements of several of the first companies traded on the Shanghai Stock Exchange covered only one and a half pages on Shanghai Securities Daily. In addition, until 1994, the accounting practices in China were primarily influenced by the old Soviet standards which made published information incompatible for the application of western data-based signaling theory assumptions ( $\mathrm{Su}, 2004)$. This meant people knew little of firm successes or failures in the years prior to their IPO.

One might argue that, even if investors have few options, they would go with the larger firms in order to offset some of their uncertainties. In a western setting, that argument makes intuitive sense. In the Chinese setting, the lack of available investment options during the first few years of the market made firm size an irrelevant signaling factor. Rather than considering the signaling effects of firm size in a western setting where there are many alternatives, in China, there were few companies offered to market players for investment. As a consequence, firm size did not constitute a factor heavily weighted in the valuation of firms at the initial stage. In other words, the impact of firm size on underpricing should be relatively minor for firms in the primitive stage because investors cannot really distinguish the signaling effects of such a factor due to lack of knowledge. This factor mean more as the market matured and investors became more sophisticated.

After January 1994, "Enterprise Accounting Systems" were put into effect which brought the published documents of publicly traded companies more in line with the western practices (Su, 2004). As the regulatory systems of the stock markets became more active, companies were required to disclose more information. Following that, we contend that market players started to consider potential signaling factors such as firm size. This would be the case in transitional economies. In these kinds of economies, the market players start with less knowledge and very little experience, not to mention little confidence in the market. As the market matures, as in the Chinese case, some of the negative or positive signaling effects applicable to western companies become relevant for them as well. The following hypothesis is based on this discussion: 
Hypothesis 4: In Chinese markets, the impact of firm size on IPOs became more important as the market matured.

The final sets of hypotheses relate to the ownership structure of Chinese firms. As a traditional socialist economy, the state's influence on the Chinese market is still pervasive (Li \& Tong, 2004). Not surprisingly, the Chinese Government tends to be the largest blockholder in a majority of the listed companies (Liu, et al., 2011). In western literature, although the results are mixed, several scholars have proposed a positive relationship between concentrated ownership and firm performance using accounting-based or market-based measures (Dalton, Daily, Certo, \& Roengpitya, 2003). Hence, in the Chinese context, one might assume that state ownership would be viewed positively by investors during the initial public offerings. However, given that the government may have a different agenda versus that of investors (e.g., job creation and expansion into targeted industries), state ownership might trigger a negative signaling effect from investors. Gu's (2003) findings support this contention. In an investigation of 68 Chinese IPOs in 1994, he found that state ownership had a negative effect on short-term IPO performance.

Building on that, the influence of state ownership may differ across the three time frames mentioned in this study. First, in the primitive stage, the state's presence might be viewed favorably due to lower perceived risk about the IPO firm. In effect, the state's presence might be seen as a valuable resource for the company thus decreasing the amount of underpricing; so the offer price set prior to the initial trading is assumed to reflect more accurately the real value of the firm. As far as the state and employee owners are concerned, such an IPO may be considered successful (Ritter, 1991). In the second stage this effect should fade because of the movement towards a market economy and ultimately lead to more underpricing in the final stage. In the final stage, the presence of heavy state ownership might be associated with a bureaucratic, non-innovative managerial style (Kornai, 1997) which is likely to trigger a negative signal about the company. Based on signaling theory, this negative signal should be reflected in the offer price (Ritter \& Welch, 2002) such that the underwriters will set the price lower to account for risks associated with new publicly traded firms - a situation that is theorized by the risk-averse underwriter hypothesis (Reilly, 1973). In the case of IPO firms, with high state ownership, underwriters would likely account for risks associated with such firms by valuing these companies lower than what they are really worth. The result in this case will be more underpricing which is actually negative IPO performance as far as the original owners are concerned, since they just left some money on the table as (Ritter, 1991). 
The situation should be reversed in the case of firms with traditional blockholders other than the state. As the market matures, just like its western counterparts, the state is expected to move away from its active role in the market if China is really on its way to becoming a free market economy and traditional blockholders, such as those in western economies (e.g., mutual funds or multinational corporations), should step in. The IPO stage of such a company structured along the lines of its western counterparts should be more successful as the presence of such blockholders may trigger a more positive signal. Thus, as the Chinese market matured, firms with more blockholder ownership should have experienced less severe underpricing. The last two hypotheses are built based on this discussion:

Hypothesis 5a: The state's presence will be negatively associated with underpricing in the first stage, become neutral in the second stage, and become positively related to underpricing in the final stage.

Hypothesis 5b: As the market matures, firms with more blockholder ownership will face less underpricing in initial public offerings.

Table 1 summarizes the proposed relationships and the specific differences we believe to be present among the three stages. In the next section, the sample data collection process is discussed and then it will be followed by the variables employed and the statistical methods used. We conclude the study by reporting the results followed by a discussion of these results and their implications. 
Table 1

\section{Summary of Hypothesized Relationships}

\begin{tabular}{|c|c|c|c|}
\hline & \multicolumn{3}{|c|}{ Stages } \\
\hline & Primitive Stage & Development Stage & Maturity Stage \\
\hline Percentage of Insiders & Highest & Lower & Lowest \\
\hline \multicolumn{4}{|l|}{ Percentage of shares } \\
\hline owned by executives & Lowest & Low & Higher \\
\hline Underpricing of IPOs & Highest & Lower & Lowest \\
\hline \multicolumn{4}{|l|}{ Impact of firm size on } \\
\hline IPO underpricing & Unimportant & Moderately Important & Important \\
\hline $\begin{array}{l}\text { Impact of presence of the } \\
\text { state on IPO underpricing }\end{array}$ & $\begin{array}{l}\text { Negative impact on } \\
\text { underpricing }\end{array}$ & $\begin{array}{l}\text { No impact on } \\
\text { underpricing }\end{array}$ & $\begin{array}{l}\text { Positive impact on } \\
\text { underpricing }\end{array}$ \\
\hline $\begin{array}{l}\text { Impact of blockholder } \\
\text { ownership on IPO underpricing }\end{array}$ & $\begin{array}{l}\text { Positive impact on } \\
\text { underpricing }\end{array}$ & $\begin{array}{l}\text { No impact on } \\
\text { underpricing }\end{array}$ & $\begin{array}{l}\text { Negative impact on } \\
\text { underpricing }\end{array}$ \\
\hline
\end{tabular}

\section{Methods}

\section{Sample Creation}

As previously discussed, we divided the development of the Chinese stock markets into three separate time frames. The first one, what we consider to be the primitive stage, starts with the opening of stock markets at the end of 1990' the beginning of 1991 and ends in 1995. The second stage, which we call the developmental stage, starts at the beginning of the year 1996 and continues to the end of the year 2000. The third stage, which we call the mature stage, begins in 2001 and goes all the way to the end of 2007. We were able to randomly select a sufficient number of companies from each time period.

We randomly selected 120 companies which went public in each stage from a total of 360. Due to missing or corrupted data in our data sources, our final sample of companies were 105 for the first stage, 117 for the second stage, and 112 for the third stage - a total of 334 companies. The China Stock Market and Accounting Research (CSMAR) database was used to gather stock and accounting data. The annual reports of the companies were gathered from various sources such as sina. com and the official website of the Shanghai and Shenzhen Stock Markets. The companies were sorted into the three time frames based on the year in which their 
shares were first traded. We ensured that no single industry dominated our sample by taking the industry codes specified by the Chinese regulatory bodies into account (via a frequency analysis for each industry). To be more specific, most of the companies did not have their primary industries specified in the archival database. Finance, information technology, utilities, and energy sectors represented $2 \%, 6 \%, 2 \%$, and $2 \%$ percent of the companies in our sample. The remaining companies are marked as others.

\section{Variables}

\section{Dependent Variable}

Underpricing: Several variables have been used in finance literature to assess IPO performance. In our study we chose to employ underpricing as the dependent variable. Underpricing is defined as the difference between a firm's IPO issue price and its first day closing price (Arthurs, et al., 2008). If this variable is negative, it means the first day closing price is larger than the initial offer price, so the company's shares were offered at a price less than the market's imputed value of the firm, and the management has left money on the table. If the situation is reversed, then the IPO is successful from the company's standpoint in that original investors initially paid more money than the company is worth. Rather than concentrating solely on IPO performance, the purpose of this paper is to show the connection between the changes in corporate governance mechanisms of the firms and the happenings in the stock market. This study assumes that the recognition of this connection is important for understanding the stages as emerging economies develop. The underpricing variable is readily available and can be used to demonstrate the differences between these stages. Hence, this variable is used as the dependent variable in the following models.

One valid argument against our choice of underpricing as a focal variable would be whether the trend of underpricing in other countries was similar to what we observed in China. In order to address this, we compared the first day returns of the IPOs in United States during the past 20 years with the ones in our sample. In China, during the time period this study covers and looking at the randomly selected companies, the average underpricing was almost $200 \%$ (which means the average first day closing price is double the opening price) while that number was around 22 percent in the United States (Ritter, 2011). In fact, this big difference between the two markets is also a support for our argument about the uniqueness of the Chinese IPO market and the related corporate governance mechanisms. 


\section{Independent Variables}

Percentage of executives on the board: This variable is used to test Hypothesis 1 . The variable is computed by using the number of executives on the board divided by the total number of directors.

Percentage of stock owned by executives on the board: This variable is used to test Hypothesis 2 . The CSMAR database includes a variable representing the percentage of shares owned by the executives of listed firms and that variable is used to operationalize executive ownership.

Firm Size: This variable is used to test Hypothesis 4. The log of total assets reported for the IPO year proxies for firm size (Gilson, 1997).

State Ownership: We chose the percentage of shares owned by the Government as the state ownership variable. These data are reported in company annual reports.

Blockholders: Shareholders who control 5 percent or more of a firm's outstanding shares are considered blockholders (Kroll, Wright, Toombs, \& Leavell, 1997). In order to test the contention in Hypothesis 5b, we used percentage of shares owned by blockholders as the independent variable.

\section{Control Variables}

International ownership is used as a control variable in our models. Although the results are mixed concerning foreign ownership's influence on Chinese stock markets (McGuinness \& Ferguson, 2005), we suspect that it has a potential impact on underpricing due to underwriters' potential relations with international investors. Chinese publicly traded firms report the amount of international ownership separately (Liu et al., 2011). The percentage of shares owned by international owners is used to operationalize this variable. As a second control variable, a dummy variable is included representing the stock market the firm is traded on (Shanghai $=1$ and Shenzhen $=0$ ) since the two markets have different types of companies just like their counterparts in the U.S. (i.e., New York Stock Exchange 'NYSE' and The National Association of Securities Dealers Automated Quotations 'NASDAQ').

\section{Statistical Techniques}

In order to test Hypotheses 1, 2, and 3, we used ANOVA and Scheffe's method to identify the differences among the three groups. ANOVA only tells if the groups are different from one another. Scheffe's Method, in parallel with ANOVA, was used to identify how different each group was from the others. 
Ordinary Least Squares were used to test the remaining hypotheses. First, the control variables were entered in the models and then the corresponding independent variables. For the purpose of investigating the differences attributed to time frames, three different regression models were estimated reflecting the three different groups of companies previously discussed. Below is the model that was used for each time period:

Underpricing = International Ownership + Stock Market Dummy + Log of Assets + State Ownership + Percentage of shares owned by blockholders.

\section{Results}

Table 2 includes results of the ANOVA and Scheffe's that we used to test Hypotheses 1,2, and 3. The mean values of percentage of executives on the board in each time frame were statistically different from one another (at $p<0.001$ ). Based on the results of the Scheffe's test, we can say that the number of executives on the board was higher in the primitive stage, declined slightly in the development stage, and still went down even further in the maturity stage. These results provide support for Hypothesis 1. In terms of Hypothesis 2, although the three groups displayed a numerical difference with regard to percentages of shares owned by the executives $(\mathrm{p}<.10)$, the Scheffe's test results did not demonstrate a significant statistical difference, and therefore Hypothesis 2 is not supported. For Hypothesis 3, the ANOVA results are statistically significant for the difference among the three time frames (at $\mathrm{p}<0.001$ ). The mean values seem to decline as we moved from the primitive stage, to the development stage, and then to the maturity stage. Scheffe's test results also provided support for this contention. In sum, Hypothesis 3 received support.

For the regression models, first the Durbin Watson statistic was used to check for autocorrelation and variance inflation factor values were estimated to test for multicollinearity. Neither of these values exceeded the critical values mentioned in the literature (Durbin-Watson score was around 2 for all groups, while the largest variance inflation factor score was around 1.7). Table 3 includes the Pearson's correlations and descriptive statistics. Table 4 includes the regression results for our various models. The results indicate that firm size is not a statistically significant determinant of underpricing in the primitive stage $(\beta=-.143, p>.10)$. In the development stage that variable becomes significant $(\beta=-.303, p<0.01)$. In the most advanced maturity stage the firm size variable is still significant $(\beta=-.369, \mathrm{p}<0.01)$. The negative sign signifies that larger companies are underpriced less as we hypothesized. Thus there is support for Hypothesis 4. 


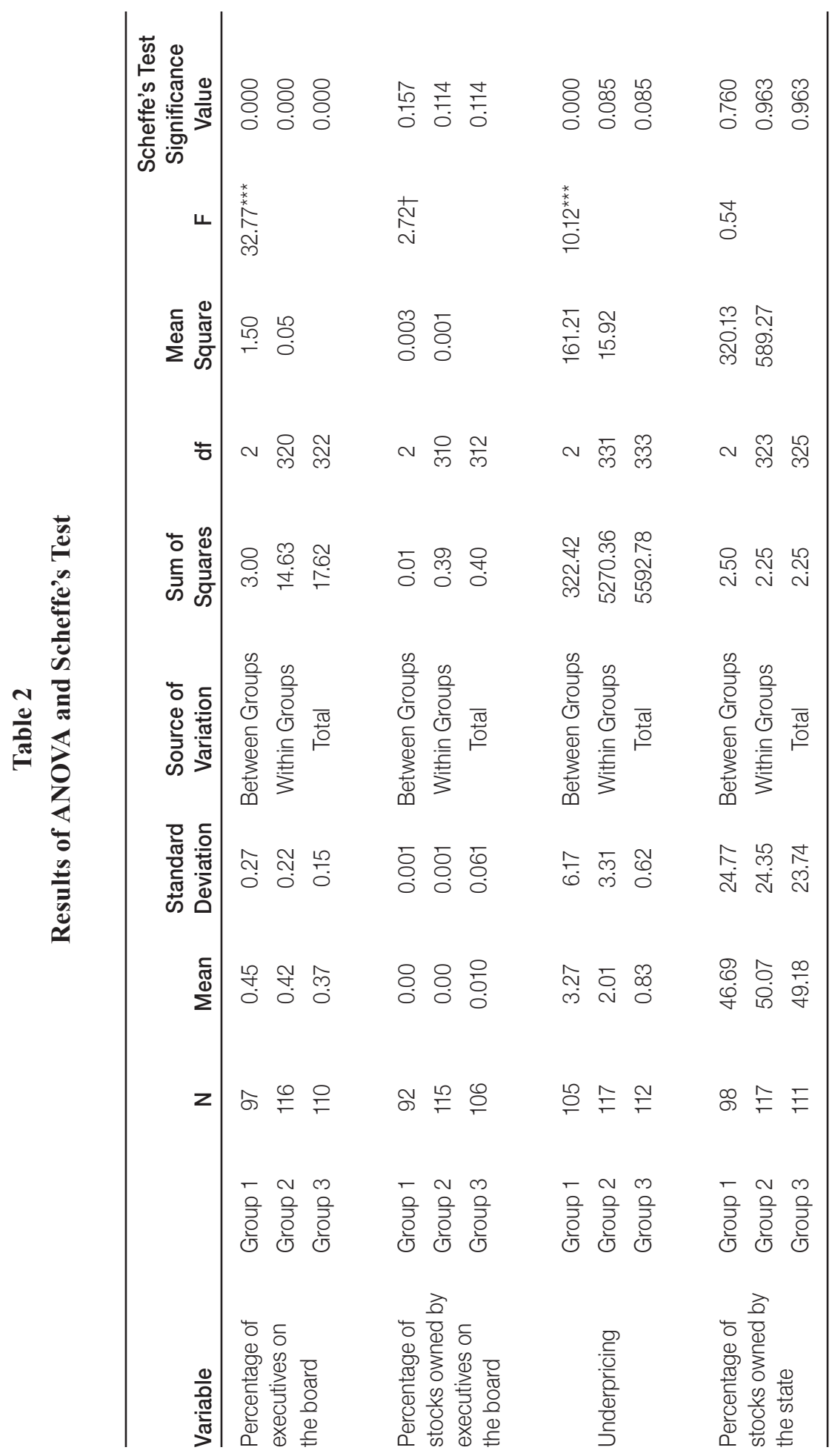


Table 3

\section{Pearson's Correlations and Descriptive Statistics}

\begin{tabular}{|c|c|c|c|c|c|c|c|c|c|}
\hline Variables & Means & s. d. & 1 & 2 & 3 & 4 & 5 & 6 & 7 \\
\hline 1. Underpricing & 2.01 & 4.10 & & & & & & & \\
\hline $\begin{array}{l}\text { 2. Percentage of } \\
\text { executives on the } \\
\text { board }\end{array}$ & 0.37 & .23 & $.13^{*}$ & & & & & & \\
\hline $\begin{array}{l}\text { 3. Percentage of } \\
\text { stocks owned by } \\
\text { executives }\end{array}$ & .004 & .04 & -.03 & -.07 & & & & & \\
\hline $\begin{array}{l}\text { 4. International } \\
\text { Ownership }\end{array}$ & 5.61 & 11.91 & -.04 & -.06 & -.04 & & & & \\
\hline $\begin{array}{l}\text { 5. Stock Market } \\
\text { Dummy }\end{array}$ & .72 & .45 & -.08 & $-.16^{\star \star}$ & -.00 & $.15^{\star \star}$ & & & \\
\hline 6. Log of assets & 9.25 & .81 & $-.21^{\star \star}$ & $-.19^{\star \star}$ & .04 & $.38^{* *}$ & $.21^{\star \star}$ & & \\
\hline $\begin{array}{l}\text { 7. Percentage of } \\
\text { stocks owned by } \\
\text { blockholders }\end{array}$ & 60.45 & 14.05 & -.05 & .01 & -.02 & -.04 & .03 & $.10 \dagger$ & \\
\hline $\begin{array}{l}\text { 8. State } \\
\text { ownership }\end{array}$ & 48.75 & 24.24 & -.07 & .08 & $-.15^{\star \star}$ & $-.18^{* *}$ & .02 & $.13^{*}$ & $.49^{\star \star}$ \\
\hline
\end{tabular}

Table 4

Multiple Regression Results

\begin{tabular}{lccc}
\hline Variables & $\begin{array}{c}\text { Primitive } \\
\text { Stage }\end{array}$ & $\begin{array}{c}\text { Development } \\
\text { Stage }\end{array}$ & $\begin{array}{c}\text { Maturity } \\
\text { Stage }\end{array}$ \\
\hline International Ownership & .04 & .04 & $.23^{\star}$ \\
Stock market dummy & -.03 & -.01 & $-.17 \dagger$ \\
Firm Size (Log of Assets) & -.14 & $-.30^{\star \star}$ & $-0.37^{\star \star}$ \\
Percentage of stocks owned by blockholders & .12 & $-.21 \dagger$ & $-.29^{\star *}$ \\
State ownership & -.03 & .04 & $.21 \dagger$ \\
R-Square & 0.03 & 0.15 & 0.19 \\
F-Value & .55 & $3.74^{\star}$ & $4.97^{\star \star \star}$ \\
\hline
\end{tabular}


Table 4 also includes the results for Hypotheses $5 \mathrm{a}$ and $5 \mathrm{~b}$. The percentage of shares owned by the state did not prove to be a significant predictor of underpricing other than being moderately significant $(\mathrm{p}<.10)$ in the maturity stage. The coefficient sign was positive in the maturity stage which signifies a negative influence by the state's presence on IPOs as the market matured. In addition, we ran a regression model in which we replaced the state variable with a binary variable indicating the state was or was not a major blockholder. However, we did not find any significance (we do not report the results of that step). Furthermore, we used ANOVA to test for differences among the three time frames with regard to state ownership but did not observe any significant difference. The mean values of the percentages of shares owned by the state were very close to one another, indicating the state's role in the market remained stable over the years. This will be further discussed in the next section. In short, Hypothesis $5 \mathrm{a}$ is only partially supported. The percentage of stock owned by blockholders did not prove to be significantly related to underpricing in the primitive stage $(\beta=-.116, p>.10)$, but was moderately significant in the development stage $(\beta=-.211, \mathrm{p}<.10)$ and strongly significant in the maturity stage $(\beta=-.286, p<.01)$. These results provide strong support for Hypothesis $5 \mathrm{~b}$. Our findings can be summarized as follows:

- Hypotheses 1, 3, 4, and 5b are supported.

- Hypothesis 5a is partially supported.

- Hypothesis 2 is not supported.

Before moving on to the discussion section, there is one other variable that is worthy of mentioning. Looking at the results reported in Table 3, international ownership was not a determinant factor during the first and second stages. However, during the third stage, this variable has a positive impact on underpricing $(\beta=-.226$, $\mathrm{p}<.05)$. This finding will also be discussed in the next section.

\section{$\overline{\text { Discussion }}$}

Hypothesis 1 proposed that the percentage of executives on the board declined as the market matured in China. We predicted that with certain recent regulations and the popularity of board independence in the West (as recommended by agency theorists [e.g., Fama, 1980]), the boards of Chinese listed companies would become more vigilant. Our results supported this prediction. There is strong support in the west for the positive effect of board independence (Kroll, et al., 2008). A theoretical explanation can be made through the use of the propositions of the 
institutional theory (DiMaggio \& Powell, 1983). At the beginning, when the mechanisms were weak, market players started with the traditional ways of doing business because they lacked experience. As the market matured, Chinese companies chose to mimic their western counterparts' business practices when they observed their success. Therefore, those companies moved away from traditional owner-managercontrolled firms toward shareholder-controlled firms. In fact, as mandated by the Sarbanes-Oxley Act of 2002 in the United States, the recommendation made by CSRC concerning having two outsiders on the board is an indication of this trend. Support for this hypothesis is a good demonstration of the process emerging economies experienced with regard to their IPO processes.

However, Hypotheses 2, which proposes that the percentage of shares owned by IPO firm executives rose as the market matured, is not supported. We did find that executive ownership is definitely higher in the maturity stage. Once again, Chinese companies are probably starting to adapt performance-based compensation schemes for their upper echelons (Hambrick \& Mason, 1984) as is the case for western firms. This trend is not obvious in the development stage but it is definitely present in the maturity stage. Obviously, due to potential effects of the state (Li \& Tong, 2004), performance-based pay for executives is not very active. The indication in our dataset is of an increase in executive ownership. As the market becomes more mature, researchers might observe a trend toward greater insider ownership continuing. This might be an area for future research.

Hypothesis 3 anticipated that underpricing would decline as the Chinese market matured. We found strong support for this contention. Going back to the information asymmetry argument made by Rock (1986), investors did not have any meaningful experience with market mechanisms and firm valuation in the primitive stage. This asymmetry probably started to dissipate as the market matured and the players gained experience and greater knowledge of Chinese companies and their businesses practices. In the future, as the Chinese market evolves to more closely parallel western markets, other factors such as underwriter prestige may begin to affect underpricing. This may be applicable to most of the emerging economies. The information asymmetry and weak signaling mechanisms are probably the main reasons for underpricing of the firms in emerging economies. As these markets mature, they may become developed economies where the market players have access to enough information and signaling effects. Hence, assessing the development processes of emerging economies' IPO structures should be done from this perspective. Both investors and academicians should expect underpricing at the beginning and should observe that underpricing may fade as the market progresses. 
Hypothesis 4, which anticipated that the impact of firm size on underpricing would increase over time, is supported. In the primitive stage, firm size did not matter at all. Previous research showed that investors in the initial years of the Chinese stock markets did not have many alternatives (Chau, et al., 1999) so the most common determinants of underpricing in other markets did not matter at that point. The data revealed that this situation changed as the Chinese market matured. This phenomenon is probably unique to transitional economies. Investors, particularly the local ones, have information about the market and how it functions at the outset. The information asymmetry concerning new firms going public is at its greatest during these times. Furthermore, underwriters, in order to attract investors, mark down IPO prices so as to assure reasonable returns for those who are brave enough to invest despite so many unknowns. "The IPOs in China represented a process of transferring ownership from Government to individual investors" (Gu, 2003: 104). In the initial stages, that is probably why firm size did not matter. However, as the market matured, investors began to have more confidence in larger firms due to their potential for survival. This may be the reason why firm size and underpricing came to have a significant negative relationship in the development and maturity stages. If firm size has a positive signaling effect, regardless of the state's influence in the Chinese context, investors chose to use firm size as a proxy to reduce information asymmetries in the 2 nd and 3 rd stages. Furthermore, the effect of size is even larger in the third stage ( $\beta=-.369$ in the maturity stage versus -.303 in the development stage) although the percentage of shares owned by the state remained the same over the years.

Our final set of hypotheses concerns the impact of state and blockholder ownership. The hypotheses predicted that the state's influence on underpricing will be negative in the first stage, will fade in the second stage, and will become positive in the third stage. In the first stage we were unable to observe any significance. In the second stage, there was not any significance either but in the third stage a moderately strong positive effect was observed. It shows that at the beginning, the state's impact did not matter. In other words, investors did not see the state as a negative or positive influence. The lack of significance continued in the second stage, but in the development stage the state's presence began to trigger negative perceptions about the value of the IPOs. In Table 2, we also report the ANOVA results for state ownership across the three different time frames. The results show that the percentage of shares owned by the state in the companies going public has stayed constant over the years. It suggests that as the major player in what is still in many ways a socialist economy, the Chinese Government is reluctant to give up its influence. Thus, investors' negative perception about the presence of state ownership due to its association 
with a bureaucratic, non-innovative managerial style (Kornai, 1997) is becoming more apparent.

The last hypothesis, which focuses on blockholder ownership, was strongly supported. At the beginning, concentrated ownership did not mean much for the investors, once again due to lack of options and information asymmetry. As the market matured, a moderately significant negative association between underpricing and percentage of shares owned by blockholders was observed. If the percentages of shares owned by the state stayed constant over the years as shown in Table 2, then this observation may easily be attributed to private blockholder ownership. Hence, firms with concentrated ownership started to be more highly valued. In the third stage, the impact of concentrated ownership became even stronger. Considering the moderately significant positive impact of the state in this last period, the strong negative relationship between concentrated ownership and underpricing tells us that strong blockholders represent a positive signaling effect on firm value. This should be of interest not only to the researchers of the area but to the Chinese Government, or to any other emerging market government for that manner. It appears that as the market matures, powerful blockholders are wanted by investors just as in the west. Future assessment of these relationships as the market becomes even more mature may provide more complete results. Researchers in the field should continue to investigate the state's influence as the market moves towards even more mature stages.

Looking at the effect of international ownership, the percentage of shares owned by international owners was not significantly related with underpricing during the primitive and development stages. However, during the maturity stage, higher international ownership resulted in less severe underpricing. This situation has two implications. First, it is a support for our argument about different factors acting differently during the three stages. Second, in transition economies, international ownership is considered to be a positive determinant of firm valuation as the market matures and the market players value those companies with international ownership more positively. As this finding is beyond the scope of this study, future researchers may choose to further investigate that topic.

\section{$\overline{\text { Conclusion }}$}

Analyzing Chinese listed companies with regard to their governance structure has been of interest to management scholars for the past decade (Chen, 2001; Firth, et al., 2006; 2007). We sought to contribute to this research stream through an investigation of IPO underpricing across different time periods. Specifically, we divided 
the history of the Chinese stock markets into three different time periods. The first, the primitive stage, involved a period when public ownership was new, the players did not know a great deal about the market, and the rules were being established. We called the second period the development stage, when the mechanisms started to become more transparent and the players gained some experience. The third and the final stage, the maturity stage, covers the recent years during which the market has evolved to emulate its western counterparts and the players are aware of the mechanisms of the market given more than a decade of experience. This distinction across time has not been made in other studies.

The results of this study indicates that the number of insiders on the boards of Chinese listed companies decreased as the market matured, but the percentage of shares owned by those executives did not move in parallel to that, although moderate significance in the last stage can be an indication of potential support in future studies. IPOs were less severely underpriced as the market matured due to better information flow, more experienced investors, and the establishment of market mechanisms. Firm size mattered much more in the development and maturity stages, indicating the applicability of signaling theory (Spence, 1973). Finally, the state is still an active shareholder in a majority of companies but its presence is starting to trigger negative perceptions about the values of the firms while powerful blockholders are expected by the market players. This is an indication of China moving away from a quasi-socialist economy and trying to adapt more free market characteristics. It is now the Chinese Government's job now to facilitate this transition. We believe it is legitimate to analyze the Chinese stock market's development in different stages as is true for other transitional economies.

The results show that the values of our dependent variables change among the three different stages, which we believe is a natural result of the distinctiveness of three time periods. Replication of this segmentation in other economies and analyzing the Chinese market from this perspective might help scholars shed new light on the unknowns of developing economies. Furthermore, based on our sample, we can say that investors might expect severe underpricing in the initial stages with larger firms gaining more in a typical IPO in transitional economies. Also, it would be too optimistic to expect the state to give up its influence over the market in the near future. We consider this issue a potentially fruitful research area.

The main limitation of this study is that we only considered the difference between the IPO price and first day closing price to be an IPO performance determinant. Use of 3rd day, 1st week, 1 month, 6 months, 1 year, and 3 years of returns is also popular in finance and management literatures. Future extension of this study 
should include analyzing different time periods after the initial listing. The second limitation is that the dataset only contained companies from Chinese markets. In the future, data from other emerging markets should be used to validate this segmentation so that the results may become more generalizable. Finally, rather than crosssectional analysis, time-series analysis may provide more promising results. For instance, analysis of the relationship between the change in corporate governance structures throughout the years and change in firm valuation after the IPO process may be used to illustrate the gradual process Chinese companies are facing.

\section{References}

Arthurs, J., Hoskisson, R., Busenitz, L., \& Johnson, R. (2008). Managerial agents watching other agents: Multiple agency conflicts regarding underpricing in IPO firms. Academy of Management Journal, 51(2), 277-294.

Buchko, A. (1992). Employee ownership, attitudes, and turnover: An empirical assessment. Human Relations, 45, 711-733.

Chau, C., Ciccotello, S. C., \& Grant, C. T. (1999). Role of ownership in Chinese privatization: Empirical evidence from returns in IPOs of Chinese A-shares, 1990-1993. Advances in Financial Economics, 4, 51-78.

Chen, J. (2001). Ownership structure as corporate governance mechanism: Evidence from Chinese listed companies. Economics of Planning, 34, 53-72.

Daily, C., Dalton, D., \& Rajagopalan, N. (2003). Governance through ownership; Centuries of practice, decades of research. Academy of Management Journal, 46(2), 151-158.

Dalton, D., Daily, C., Certo, S., \& Roengpitya, R. (2003). Meta-analyses of financial performance and equity: Fusion or confusion? Academy of Management Journal, 46, 13-26.

Dalton, D., Daily, C., Johnson, J., \& Ellstrand, A. (1999). Number of directors and financial performance: A meta-analysis. Academy of Management Journal, 42(6), 674-686.

Deng, H., \& Dorfleitner, G. (2008). Underpricing in Chinese IPOs-some recent evidence. Applied Financial Economics, 18(1), 9-.

DiMaggio, P. J., \& Powell, W. W. (1983). The iron cage revisited: Institutional isomorphism and collective rationality in organizational fields. American Sociological Review, 48(2), 147-160.

Fama, E. F. (1980). Agency problems and the theory of the firm. Journal of Political Economy, 88(2), 288-307. 
Firth, M., Fung, P., and Rui, M. (2006). Firm performance, governance structure and top management turnover in transitional economy. Journal of Management Studies, 43(6), 1289-1330.

Firth, M., Fung, P., \& Rui, M. (2007). How ownership and corporate governance influence chief executive pay in China's listed companies. Journal of Business Research, 60, 776-785.

Fischer, H. M., \& Pollock, T. G. (2004). Effects of social capital and power on surviving transformational change: The case of initial public offerings. Academy of Management Journal, 47(4), 463-481.

Gersick, C. (1991). Revolutionary change theories: A multilevel exploration of the punctuated equilibrium paradigm. Academy of Management Review, 16(1), 10-36.

Gilson, S. C. (1997). Transactions costs and capital structure choice: Evidence from financially distressed firms. The Journal of Finance, 52(1),161-196.

Gu, Y. A. (2003). State ownership, firm size, and IPO performance: Evidence from Chinese "A" share issues. American Business Review, 21(2), 101-108.

Hand, J. R. (2007). Determinants of the round-to-round returns to pre-IPO venture capital investments in U.S. biotechnology companies. Journal of Business Venturing, 22(1), 1-28.

Hambrick, D. C., \& Mason, P. (1984). Upper echelons: The organization as a reflection of its top managers. Academy of Management Review, 9(2),193-206.

Heeley, M. B., Matusik, S. F., \& Jain, N. (2007). Innovation, appropriability, and the underpricing of initial public offerings. Academy of Management Journal, 50(1), 209-225.

Hua, J., Miesing, P., \& Li, M. (2006). An empirical taxonomy of SOE governance in transitional China. Journal of Management and Governance, 10(4), 401-433.

Ibbotson, R., Sindelar, J., \& Ritter, J. (1988). Initial public offerings. Journal of Applied Corporate Finance, 1, 37-45.

Jain, B. A., \& Kini, O.(1994). The post-issue operating performance of IPO firms. Journal of Finance, 49, 1699-1726.

Jensen, M., \& Meckling, W. (1976). Theory of the firm: Managerial behavior, agency costs, and ownership structure. Journal of Financial Economics, 3, 305-360.

Kao, J., Wu, D., \& Yang, Z. (2009). Regulations, earnings management, and postIPO performance: The Chinese evidence. Journal of Banking and Finance, $33(1), 63-$.

Kornai, J. (1997). Editorial: Reforming the welfare state in postsocialist societies. World Development, 25(8), 1183-1186. 
Kroll, M., Walters, B., \& Le, S. (2007). The impact of board composition and top management team ownership structure on post-IPO performance in young entrepreneurial firms. Academy of Management Journal, 50(5), 1198-1126.

Kroll, M., Walters, B., \& Wright, P. (2008). Board vigilance, director experience, and corporate outcomes. Strategic Management Journal, 29(4), 363-382.

Kroll, M., Wright, P., \& Elenkov, D. (2002). Acquisition returns, increase in firm size, and chief executive officer compensation: The moderating role of monitoring. Academy of Management Journal, 45, 599-608.

Kroll, M., Wright, P., Toombs, L., \& Leavel, H. (1997). Form of control: A critical determinant of acquisition performance and CEO rewards. Strategic Management Journal, 18, 85-96.

Le, S., Kroll, M., \& Walters, B. (2010). The impact of institutional changes on corporate governance mechanisms in transition economies. Journal of Management \& Governance, 14(2), 91+.

Li, K., \& Tong, L. (2004). Chinese industrial policy and the reduction of state-owned shares in China's listed companies. Pacific Economic Review, 9(4), 377-393.

Liu, Y., Atinc, G., \& Kroll, M. (2011). The unique nature of Chinese corporate governance practices. Journal of Business Strategies, 28(1), 29-58.

Ma, S. (2007). Information asymmetry and valuation uncertainty, the determination of China's IPO allocation procedures. Applied Financial Economics, 17, 271-284.

McGuinness, P., \& Ferguson, M. (2005). The ownership structure of listed Chinese state-owned enterprises and its relation to corporate performance. Applied Financial Economics, 15(4), 231-246.

Reilly, F. (1973). Further evidence on short-run results for new issue investors. Journal of Financial and Quantitative Analysis, 8, 83-90.

Ritter, J. (1991). The long-run performance of initial public offerings. Journal of Finance, 46, 3-27.

Ritter, J., \& Welch, I. (2002). A review of IPO activity, pricing, and allocations. The Journal of Finance, 57(4), 1795-1829.

Ritter, J. (2011). Jay Ritter's web-site. Retrieved December 16, 2011, from bear.warrington.ufl.edu/ritter/ipodata.htm

Rock, K. (1986). Why new issues are underpriced? Journal of Financial Economics, $15,187-212$.

Sanders, W. M., \& Boivie, S. (2004). Sorting things out: Valuation of new firms in uncertain markets. Strategic Management Journal, 25(2), 167-186. 
Spence, A. (1973). Job market signaling. Quarterly Journal of Economics, 87, 355-379.

Stinchcombe, A. (1965). In J. G. March (Ed.), Social Structure and Organizations. Chicago: Rand McNally.

$\mathrm{Su}$, D. (2004). Adverse selection versus signaling: Evidence for the pricing of Chinese IPOs. Journal of Economics and Business, 56, 1-19.

Sun, L., Li, T., \& Zou, L. ( 2005). State ownership, corporate performance, and parameter heterogeneity: A quantile analysis on China's listed companies. Journal of Economics, 60+.

Wang, C. Y. (2005). Ownership and operating performance of Chinese IPOs. Journal of Banking and Finance, 29(7), 1835-1856.

Wright, P., \& Kroll, M. (2002). Executive discretion and corporate performance as determinants of CEO compensation, contingent on external monitoring activities. Journal of Management and Governance, 6(3), 189+.

Zhou, Z., \& Zhou, J. (2010). Chinese IPO activity, pricing, and market cycles. Review of Quantitative Finance \& Accounting, 44, 483-503.

Zhou, Z., \& Zhou, J. (2011). Chinese IPO market cycles. The Chinese Economy, 44(5), 55-71.

\section{Biographical Sketch of Authors}

Guclu Atinc received his D.B.A. from Louisiana Tech University. He is an Assistant Professor of Management at Drake University. His current research interests are in the area of upper echelons and boards of directors in young entrepreneurial firms and on the impact of environment in strategic decision making. His research appeared in journals like Organizational Research Methods, Journal of Managerial Issues and Journal of Business Strategies.

Yan Liu received her D.B.A. from Louisiana Tech University. She is an Assistant Professor of Management at United States University. Her research interests include proactive behavior, leadership, organizational justice, deviance behavior as well as corporate governance mechanisms of Chinese organizations.

Mark Kroll is the Dean of the School of Business at the University of Texas at Brownsville. He received his D.B.A. from Mississippi State University. His research interests include corporate governance, post-IPO firm performance, and strategic leadership of entrepreneurial firms.

Bruce A. Walters is the Edward L. Moyers Professor of Management and Department Chair of Management and Information Systems at Louisiana Tech Uni- 
versity. He received his Ph.D. from the University of Texas at Arlington. His current research interests include young entrepreneurial firms, corporate governance, and strategic decision processes. His research has appeared in several journals, including Academy of Management Journal, Strategic Management Journal, Journal of Management, Strategic Organization, and Journal of Business Research. 
